\title{
Research on Promoting Teacher Profession Enhancement Based on Five Disciplines
}

\author{
Weifeng Zhao \\ Human Resources Office, Wuhan University of Technology, Wuhan, P. R. China, 430070 \\ 515529518@qq.com
}

Keywords: Five disciplines; College teachers; Profession enhancement

\begin{abstract}
Profession enhancement of college teachers is not only their value pursuit but also the kernel of college educational reform and construction. However, though it has been emphasized a lot, there are still some problems. Thus, this paper analyzes that enhancing college teachers with five disciplines based on the theory of learning organization is an effective approach to promote their profession enhancement.
\end{abstract}

\section{Introduction}

The profession enhancement of university teachers is not only their individual value pursuit but also the power source to improve the quality of talents training, the level of scientific research and the ability of social service. Obviously, domestic colleges and universities in recent years have attached more and more importance to it. Nevertheless, the practical effect still exposes some problems.[1]Firstly, the three-to-five-day centralized training of new teacher induction, which focalizes unified training plans and activities, always negatively ignores their practical development of profession and actual needs. Secondly, kinds of "talent projects" at different levels or types which attempt to advance their profession development by selecting so-called talents beforehand actually spoil teachers by excessive enthusiasm. Thirdly, the profession identity of teacher falls into a wrong path in which some teachers simply regard teacher as a way to make a living while leaving their mission of education, value orientation and responsibility out. Fourthly, during the process of profession enhancement, most teachers will face their career plateau and then lose their motivation to teach.

\section{Research Method}

Nowadays, the academic circle sums the profession enhancement theory up in three orientations: ration-orientated, practice-reflection-orientated and ecology-orientated [2]. Guidance, Training and Assistance are the three traditional methods in Improving the Teacher's Engineering, while the quality learning organization [3], the best place for teacher profession enhancement, can not only increase teachers' intelligence and energy but also extend their personality and build harmonious relationship with others. Based on the theory of learning organization, proposed by Peter M. Senge, it is a good choice to obey the "five disciplines" as follows [4]

\section{Results}

Personal Mastery: the Power Source of Teacher Profession Enhancement. Domestic colleges and universities are advancing comprehensive reform -- shifting from the external development to internal development -- to establish a new concept of "education orientated, quality first". During the process of reform, transformation and quality improvement, teacher is the major force. High as their education degree is, they still have to engrave the sense of personal mastery in their mind with which they will be qualified to be a good teacher as well as a great scholar.

The teaching profession objectively requires teachers should have the "bucket of water" in his mind can be updated constantly. There are three ways for teachers to realize personal mastery. What comes first is lifelong hard work and self-transcendence. A college master can not become an 
excellent teacher until he sticks to lifelong learning, perception and practice. That means, an excellent teacher should "be able to learn" under the consciousness of self-development, " be eager to learn" from the international motivation of learning, " be good at learning" through some good learning strategies and "stick to learning" based on strong perseverance, which all eventually drive people to " be perseverant at learning" and " be insatiable in learning" for life long. Through lifelong learning, he can update his professional knowledge and expand his knowledge fields; both respectively break his limitation of longitudinal knowledge and horizontal knowledge. The second way is to maintain creative tension and constant self-pressure. It is true that college teachers will not advance smoothly all the time, and instead they will face failure. But that is simply the difference between the reality and necessity. Indeed, failure is the mother of success. It can help them reflect on previous incorrect cognition, find the reason of failure and determine their goals. The third way is to overcome the existing problems and constantly change their goals. It is well-known that Stephen Hawking, suffering from muscle atrophic amyotrophic lateral sclerosis, overcomes kinds of problems and finally becomes one of the best theoretical physicists ever after Einstein. It is his goals updating and personal mastery that contribute his great success. At this stage, teachers can realize personal mastery with four shifts. They are: shift from an inheritor of human civilization to a developer of talents, shift from a traditional teaching man to an educator of proselytizing, instructing and dispelling doubt, shift from an indoctrinator of existing knowledge to an instructor of students, shift from a bookworm to a social volunteer with rich responsibility.

\section{Improve Mental Models: Endogenous Mechanism of the Profession Enhancement}

Some British scholars like Boydell T. hold that learning organization can "facilitate the learning of all participants, constantly transform them and improve their mental models". Here, the author holds that teachers can improve their mental models by three approaches as follows [5]

Firstly, frequent self-reflection is important. Way early in 1989, an American psychologist Posner proposed that "teacher development = experience + reflection". [6] That means, reflection, a process to study some seemingly common education phenomena around, is one of the most important qualities for a teacher. Teaching practice is the updating source of teacher development while reflection and inquiry are its internal motivation. Professor Ye Lan, a famous educator in China, also points that "a teacher will never be successful by writing lesson plans unless he keeps writing teaching reflections for three years". Besides, Professor Lin Chongde in Beijing Normal University indicates that "excellent teacher $=$ teaching process + reflection". Therefore, if college teachers can establish the concept of reflective teaching, they will develop over their constant reflection.

Secondly, frequently looking into the mirror of the mind is another important way. Actually, the hidden mind-mirror is in front of everyone with the purpose of correcting their mind and thought. Most often, teachers use this mind-mirror to reflect other teachers and hold that they are superior to other teachers. It is common that scholars always tend to scorn each other. But it is not an correct way to improve their mental models. Instead, they should turn around the mind-mirror to themselves, to constantly reflect their attitude, thought and behaviors. After this self-cultivation, they can remove the mind of self-centeredness, self-conceit and reshape themselves with humility and enterprising capacity. It is acknowledged that only those humble people will behave with broad mind and finally reach to a higher level of learning and conducting themselves.

Thirdly, behaving with open mind is also important. Hugo has pointed that "the sky is wider than the sea while the human mind is broader than the sky". Cai Yuanpei also proposed words of wisdom that "the sea embraces all rivers, tolerance accordingly embraces everything". These famous warnings all instruct college teachers to open their mind to different opinions, to people with different personalities, to others' strengths and to others transcendence. When they lessen their prejudice, autism and jealousy, everything surrounding them will be very interesting, lively and valuable. 


\section{Build Shared Vision: the Noble Pursuit of Teacher Profession Enhancement}

When building shared vision, the organization should well handle the relation between personal vision and shared vision. That means, on one hand, colleges should encourage teachers to develop their personal vision. Without personal vision, they will not have their own ideas but to follow others' vision unwillingly. On the other hand, shared vision is born of personal vision, but its creative tension is way stronger than that of personal vision. Generally speaking, there are three patterns as follows to build shared vision [7].

The first one is the cohesive shared vision. That means, a group of teachers, previously holding the same or similar personal vision, collect each one's vision as the shared vision of the learning organization they spontaneously established before. The shared vision of a project team or research team is a typical example of this pattern.

Another pattern is the condensed shared vision which is intended to dig out the common images in their deepest mind and then condense them as the shared vision by their full discussion. A typical example is the shared vision born of those groups of homogeneous and like-minded teachers.

The last one is the cultivating shared vision. Usually, taking the high status, positive effect and significant influence of the authoritative person into consideration, the organization will put his personal vision as the kernel of their shared vision and then infiltrate it into the whole group of teachers. That is setting the vision of certain authoritative person as the shared vision the whole group of teachers. The shared vision of those teacher groups which consist of the old, the middle-aged and the young and focus on passing on knowledge, helping others and instructing others is such pattern.

\section{Team Learning: the Efficient Way for Teacher Profession Enhancement}

The theory of learning organization advocates team learning which mainly emphasizes cooperative learning and group intelligence development of the whole group. This is an innovative way for teacher profession enhancement [8]. Each teacher in the team, whatever his role is, is a learner. Though some teachers may embrace more professional knowledge and experience in certain fields, all of them still have their own strengths and weaknesses. Thus, each of them should study autonomously and learn from others spontaneously. Team interaction and mutual consultations have more remarkable effect on teachers than their independent learning. In other words, team learning can make the most of teachers' intelligence, much higher than that of any individual one. Team learning doesn't mean isolated self-study but collaborative learning among teachers. It not only advocates individual learning and intelligence development but also emphasizes cooperative learning and intelligence development of the whole team. In the grass-rooted teaching organization, teachers can acquire knowledge and skills theoretically and practically by communicating, discussing and sharing. With these knowledge and skills, they will be clearer about what to teach, how to teach and then do better in their job which will finally contribute to the improvement of teachers' personal intelligence system. If the teacher team learning in college becomes the order of the day, it will improve their psychological quality, drive their profession enhancement and prevent their job burnout.

\section{System Thinking: the Crux of Teacher Profession Enhancement}

As a college teacher, he is not only required to master solid professional theoretical knowledge, adept teaching skills and noble virtues but also encouraged to be capable of system thinking [9].

The improvement of their capacity of system thinking is mainly embodied in "three shifts". Firstly, it shifts from focusing on individual event to the underlying elements of the system. That means, teachers' system thinking about teaching and research doesn't simply focus on individual event but to the relationship and interactive patterns among all details behind each incident as well as their development trend. In short, it requires college teachers to gain insight into the underlying factors behind each incident. Secondly, it shifts from linear thinking to annular thinking. 
Traditionally, teachers are accustomed to thinking about the cause and the result linearly, namely the cause resulting in the result. However, in practical teaching and research work, they should adjust to annular thinking which holds that the cause and the result may be annularly interactive instead of biunique relationship. According to this thinking, the cause results in the result while the result may result in other results or even result in other causes of some certain causes. Thirdly, it shifts from the theory of mechanical reduction to the theory of whole generation [10]. If teachers prefer to study things separately, no matter how fine the division or how deep the study, they will never find out the characteristics of the whole system. In practical teaching, some teachers are self-centered, caring about themselves only and seeking benefits for themselves all the time. Thus, they have no one to cooperate with and finally become nobody. However, in the learning organization, they will be required to establish overall-situation-orientated, future-orientated and result-orientated thinking. As a small cell inside their inner system, each teacher should unlimitedly measure everything with their open minds, interactive and mutual-affected thinking patterns. They also should study on the movement rules of things from all-round and different angles, thus they can keep their development directions with their organization correctly and spontaneously. Accordingly, their profession level will be raised and the overall performance of the organization will be improved.

\section{Conclusion}

Although the university teachers obtain high educational degrees, which can not necessarily result in the qualification of being a university teacher. Only by transcending oneself, could a well-educated person become a qualified teacher and scholar. Teachers' different mental model will result in different behavioral pattern. When the teacher's mental model consistent with law of development of objective things, it will bring positive incentive function. Conversely, it will bring negative inhibition. There are three patterns to build shared vision including the cohesive shared vision, the condensed shared vision and the cultivating shared vision, which are appropriate for different teacher groups. Team Learning brings multiplicative effects to teacher's professional development. Strengthening the capacity of System Thinking is the inner requirement in teacher professional enhancement.

\section{References}

[1] Lu Guanghui. Teacher training: Problems and strategies [J].vocational education research, 2007, No.5, p.61-62 (In Chinese).

[2] Department of education of the Ministry of education. The theory and practice of education [M]. Beijing: People's education press, (1989) p.553 (In Chinese).

[3] ZHANG Anfu, JIN Min. Guidance, Training and Assistance in Improving the Teacher's Engineering Quality [J]. Journal of National Academy of Education Administration, 2015, No.4, p. 8-11 (In Chinese).

[4] Peter Senge. Fifth disciplines: the art and practice of learning organization [M]. Guo Jinlong, trans. Shanghai: Joint Publishing Press, 1998, p.42.

[5] Pedler M., Burgoyne J., Boydell T. The Learning Company: A Strategy for Sustainable Development [M]. New York: McGrawHill, 1992, p.1.

[6] Calderhead, P.Gates. Conceptualizing Reflection in Teacher Development [M] The Falmer Press, 1993, p.123.

[7] Lin Yeshu, Lin Gaobiao, Hu Haijian. Strategy of teacher intelligence development from the perspective of learning organization [J]. Journal of Hebei Normal University Education: Science Edition, 2010, No.1, p.11-14 (In Chinese).

[8] Ye Cuiying. Learning organization and the development of college teachers [J]. China Adult Education, 2009, No.22, p.24-25 (In Chinese). 
[9] Zhang Anfu, Jin Min. System thinking of the construction of young college teachers [J]. China University teaching, 2015, No.3, p.67-71 (In Chinese).

[10] Ye Liguo. Breakthrough of Five major theories in system science J]. Science and technology management, 2011, No.9, p.31-34 (In Chinese). 